InOedia $\quad \begin{aligned} & \text { InMedia } \\ & \text { The French Journal of Media Studies }\end{aligned}$

8.1. $\mid 2020$

Ubiquitous Visuality

\title{
Kim Wilkins, American Eccentric Cinema
}

New York: Bloomsbury, 2019, 224 pages

Julie Assouly

\section{OpenEdition}

Journals

Electronic version

URL: http://journals.openedition.org/inmedia/2342

DOI: $10.4000 /$ inmedia.2342

ISSN: 2259-4728

Publisher

Center for Research on the English-Speaking World (CREW)

Electronic reference

Julie Assouly, "Kim Wilkins, American Eccentric Cinema", InMedia [Online], 8.1. | 2020, Online since 15 December 2020, connection on 26 January 2021. URL: http://journals.openedition.org/inmedia/2342 ; DOI: https://doi.org/10.4000/inmedia.2342

This text was automatically generated on 26 January 2021.

(C) InMedia 


\section{Kim Wilkins, American Eccentric Cinema}

New York: Bloomsbury, 2019, 224 pages

Julie Assouly

\section{REFERENCES}

Kim Wilkins, American Eccentric Cinema, New York: Bloomsbury, 2019, 224 pages

1 In American Eccentric Cinema, Kim Wilkins offers to define and decipher the eccentric mode in American cinema, a very challenging effort that deserves praise in itself. First, because the existing theoretical framework is dense and growing, which complicates any attempt at building on it. Wilkins's corpus of films is indeed already encompassed in a certain number of theories that she had to carefully consider before unfolding her own. Second, because she defines eccentric cinema by drawing constant parallels with New Hollywood films, thus striving to inscribe her approach in American film history as well as theory. Third, because eccentricity is a mode that complements genres rather than qualifying as one, which makes it difficult to establish a list of eccentric films (the introduction does not provide a clearly determined corpus). All in all, the validity of Wilkins's eccentric mode is put to the test by any reader familiar with preexisting theories such as the New Sincerity, smart cinema, the quirky, or metamodernism, who will instantly raise the fundamental question: "so, what's new here?"

What is new is the clever filiation drawn with films of the New Hollywood through the lens of existential anxiety so as to reveal how eccentric cinema navigates between irony and sincerity. Wilkins considers existential anxiety as the reason for both New Hollywood and eccentric film characters' use of irony as a defense strategy, and she points out that this behavior in both cases is not cynical but deeply sincere. Yet eccentric films differ from New Hollywood productions in the type of existential anxiety their characters experience, which she deems more individual and informed by the neoliberal moment, whereas anxiety in the 1960s and 1970s was more related to a 
reevaluation of the American - traditional, bourgeois - system. In that respect, she insists on the ahistoric quality of eccentric films as they focus on individual crises that are disconnected from socio-political events (e.g. the films have no political commitment, their protagonists are usually white, male, and well-off).

In her very thorough study of eccentric cinema, Kim Wilkins endeavors to demonstrate how a category of American films that emerged in the 1990s, dwelling on existential crises and departing from mainstream film conventions, can in fact be connected to films of the New Hollywood Era in the way they "demonstrated an American cultural uneasiness and disconnection from their contemporary society" (2). She contends that the themes of existential anxiety and the need to connect with others, enable a parallel between eccentric and New Hollywood films such as The Graduate, Easy Rider or Five Easy Pieces, which dwelled on the social alienation and isolation of characters at odds with mainstream society (and were formally influenced by the French New Wave and Italian Neorealism). Dwelling on Thomas Elsaesser's study of these films, she concludes that "American eccentricity can be therefore seen as a contemporary reimagining of Thomas Elsaesser's 'pathos of failure'- the inability of the New Hollywood 'unmotivated hero' to fulfill the narrative functions of the classical Hollywood protagonist - to pursue a goal or react to a challenge presented." (11) She also interprets the emphasis on failure in these New Hollywood films as a criticism of the American ideals established in the Declaration of Independence - "the right to life, liberty and the pursuit of happiness"- which is in keeping with the Countercultural movement pervading American society in the 1960s. Existential anxiety as displayed in American eccentric films, by opposition, is a symptom of individual neoliberalism, as they "mobilize the textual strategies of postmodernism to articulate existential anxiety with sincerity in the neoliberal context." (13) Irony and reflexivity emphasize the ahistoricity at play in these films which characterizes a shift from modernity to postmodernity as defined by Frederic Jameson. According to Jameson, the lack of depth or flatness conveyed by postmodern texts is due to the weakening of history and affect. Following this idea, Wilkins relates the intertextuality that operates in eccentric films to an attempt at asserting their "Americanness" so as to compensate for the films' ahistoricity.

Wilkins traces the use of the phrase "eccentric cinema" back to a 2004 review of I Heart Huckabees (Russell 2004) by Armond White who included Paul Thomas Anderson, Spike Jonze, Wes Anderson, Alexander Payne and Sophia Coppola to his list of auteurs of eccentric films. He defined these films as displaying existential anxiety through characters experiencing "a sense of alienation from collective social experience". Wilkins then expands her theoretical corpus to further define what eccentric cinema represents within the field of film studies. Drawing on Jesse Fox Mayshark's 2007 essay on "Post-pop Cinema," Baudrillard's "Beyond the Vanishing Point of Art" (1989) and David Foster Wallace's "E Unibus Pluram: television and us fiction" (1993), she determines that, by marking a return of sincerity combined with postmodern techniques (e.g. new plot structures, self-awareness) and irony, eccentric films are an answer to endless simulation - or simulacra in Baudrillard's terms - in postmodern art. To her, eccentric films "use irony to sincerely articulate existential anxiety" thus relating this mode to the "broader category of the New Sincerity." (9)

In a disambiguating first chapter, the author unfolds a range of theories (namely New Sincerity, metamodernism, the "quirky" mode and "smart" cinema) relating the 
concept of American eccentricity to independent cinema, and refocusing on irony and existential anxiety to come up with a full definition. The eccentric mode is thus defined as part ironic part sincere, both entertaining and serious, with an ironic expression that relies on a "space between the said and the unsaid" (31). She relates this mode to the broader New Sincerity trend (Collins, Buckland) distances it from "smart cinema" (Sconce, Perkins) that expresses cynicism and at turn even disdain, but connects it with the quirky mode (McDowell) in the way irony serves a sincere engagement. Yet the quirky mode operates mainly in the melodramatic and comedic registers which relate it to the "cool" (as opposed to the mainstream), whereas eccentricity "is not a fashionable affectation, but rather a constant state of unshakable oddity embodied by an individual" (52). She isolates the thematic features and textual characteristics of the eccentric mode as: (1) intertextuality, (2) sincerity, quirkiness (absurd aesthetic), (3) irony both reflexive and sincere, (4) overtly constructed characters and cinematic worlds that do not deter audience alignment, (5) existential anxiety.

6 The second chapter considers eccentricity through its tendency to transgress and subvert genres with a particular attention to the road movie. She thus traces existential anxiety back to New Hollywood road movies which dwelled on the Western mythology to better debunk the myth of the American Dream (e.g. Easy Rider, Two-Lane Blacktop). The relationship between New Hollywood and eccentric films clearly emerges in the way they both expose existential anxiety in relation to failed American mythologies. The choice of the road as a common motif within the two trends is therefore justified by the way this "liminal space" generates anxiety as opposed to the ease and freedom it stood for in American mythology. Yet, what validates her postulate that The Darjeeling Limited and Being John Malkovich can be considered as eccentric road movies, is their eccentric reappropriation of road movie genre conventions, keeping its introspective essence while eliminating the act of driving and the road itself - one takes place on a train, the other inside a head.

7 Chapter 3 focuses on characterization and continues exploring the connection between New Hollywood and eccentric films, mainly through examples taken from Wes Anderson's eccentric characters who were inspired by "idealized" or "cinematized" peers (such as Benjamin in The Graduate). She demonstrates that contrary to what she calls "the cinematic peers mode," the "overtly cinematic" characters evolving in eccentric films such as Wes Anderson's, are not meant to create viewers' alignment but a distance, in that respect they can be related to "smart films" characters (Sconce, Perkins). Dwelling on Murray Smith's theories on characters in fiction (1995) which consider recognition, alignment and allegiance as the three levels of spectatorial engagement with fictional characters, Wilkins underlines the importance of real-life frustrations and characters embodying societal issues to enable such engagement. Informed by the countercultural movement, New Hollywood directors created "cinematized peers" who can transcend the cinematic frame. Eccentric characters on the contrary are defined as "overtly cinematic," which deprives them of extra-textual life, as they are detached from the contemporary socio-political context, the spectator may only engage in "temporary emotional attachment" (92) with these characters in place of alignment or allegiance. This theory is then well developed and validated through a study of such characters in Wes Anderson's oeuvre that, the author deems, fits "squarely within the parameters of American eccentricity" (97). 
8 Further unfolding the parallel she draws with New Hollywood films, in chapter 4, Wilkins relates eccentricity to hyper-dialogues - "the intensified, unevenly fluctuating, and often ironically inflicted use of dialogue to distance anxiety" (17) - as opposed to the more "naturalistic" New Hollywood approaches favoring the spectator's alignment. Inaugurating the chapter is a comparison between Preston Sturges and Anderson's use of hyper-dialogue developed by Jeff Jaeckle (2012) so as to expose their "unconventional, constructed and performative nature" in Jaeckle's words. Similarly, eccentric films will use hyper-dialogue to distance anxiety, alternating between irony and sincerity, which Wilkins relates to metamodernism in the way it mediates between modernism and postmodernism.

In the fifth and last chapter, Wilkins argues that eccentric cinema is subservient to eccentric worlds - as opposed to the New Hollywood realistic world - that defy realism and delve into a rich web of intertexts. She contends that the artificiality or unrealistic nature of these worlds does not prevent the audience from being immersed into them and concerned by the eccentric narratives occurring in these "fictional yet deeply affecting spaces". This final theme complements the previous chapters on overtly cinematic characters and hyperdialogues. Wilkins demonstrates how, although constructed and "consciously fictional," eccentric cinematic worlds are indeed "affecting spaces." Comparing them to Joseph Cornell's boxes, she argues that their artificiality, echoed by equally artificial characters and dialogue, once again favors temporary emotional attachment encouraged by "a safe, mediated distance" from which to safely observe existential anxieties (149).

Kim Wilkins offers a well-written, well-documented, thorough study that relies on a solid knowledge of film theories, and a very large selection of films. Her focus on New Hollywood films, though limited to a few examples, appears as a very convincing sociohistorical framework to explicit and justify the interest of the eccentric mode in a contemporary, neoliberal context, as an augmentation of existing genres that is in keeping with the metamodernist trend. This theory proves useful to bridge the gap between independent cinema in the sixties and a marginal, yet important, production of films that reflects a mood, rather than delivering a political or aesthetic statement (as the French New Wave and the New Hollywood films did). Yet, the eclectic nature of the eccentric mode restricts any attempt at plainly establishing a group of clearly related films (Wilkins considers films as different as Magnolia, Marie-Antoinette, Punch Drunk Love and The Life Aquatic as eccentric). Although her analyses of these films in the light of her definition of the eccentric mode are convincing individually for all the reasons developed in this review, they may lack cohesion as a group under the label of American eccentric cinema.

\title{
AUTHORS
}

\author{
JULIE ASSOULY
}

Université d'Artois 